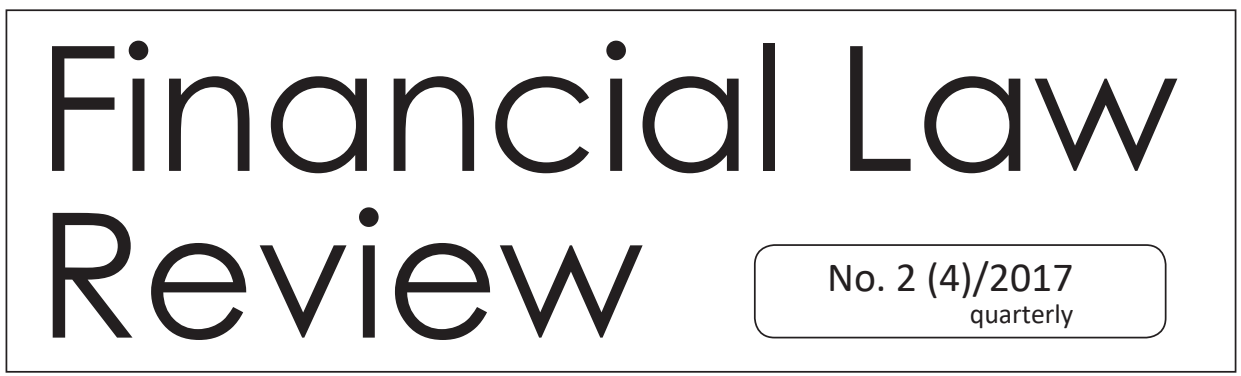

UNIVERSITY OF GDAŃSK • FACULTY OF LAW AND ADMINISTRATION

http://www.ejournals.eu • http://czasopisma.bg.ug.edu.pl

\title{
THE PROCESS OF MUNICIPALIZATION OF THE STATE IN A SPIRIT OF THE IDEA OF SUBSIDIARITY AND IN ACCORDANCE WITH THE EUROPEAN CHARTER OF LOCAL SELF-GOVERNMENT AT THE EXAMPLE OF POLAND FROM 1990 TO 2015
}

dr Tomasz Sowiński

In this study I would like make a scientific reflection on the process of the municipalization of the society and the decentralisation of the public administration structures in the last quarter-century in Poland. I am convinced to the idea of local government, but also the existence of an effective state, which may be achieved solely through the complementarity of the solutions and keeping the suitable balance concerning the particular entities of public administration.

I advance a thesis that the solutions which have been applied so far are proper [although undoubtedly some mistakes were also made] and I strongly support

\footnotetext{
1 The article is a reprint of the article originally published in Finansowanie samorządu terytorialnego i jego zadań a Europejska Karta Samorządu Lokalnego. Local government financing and European Charter of Local Self-Government, J. Gliniecka, A. Drywa, E. Juchniewicz, T. Sowiński (red.), CeDeWu Warszawa 2016
} 
the necessity of the continuation of the 1990 local government reform ${ }^{2}$ with its development in $1998^{3}$, and also the need to go another step further with the idea of decentralisation and devolution of the public administration.

An integral part of decentralisation of public authority is also providing appropriate involvement of particular self-government communities in the distribution of public resources which reflect their needs, what is best captured by article 9 of the European Charter of Local Self-government ${ }^{4}$ (further - ECLSG ${ }^{5}$ ) ratified by the Republic of Poland, likewise by most states in Europe ${ }^{6}$.

I will try to present the vision of the expected modifications, risks which future reformers may encounter and a handful of arguments for particular solutions. The vision which one may agree with or not, nevertheless it is worth to reflect on the proposed solutions since they might lead to a better and more efficient activity of the state, but when incorrectly implemented, they might become the cause of its destruction, chaos with regard to the division of competences, a platform for political games on the level of ambition or political expediency which has nothing to do with the good of the state.

Driven by the bad experience, I observe that important amendments are made in the spirit of pre-election populism in a scandalous form or rather without the legal form and due diligence while creating the law regulating the functioning

\footnotetext{
2 The Act of 8 March 1990 on the Local Government (Journal of Laws of 1996 No. 13, Item 274, as amended)

3 The Act of 4 September 1997 on Branches of Government Administration (Journal of Laws No. 141, Item 943 , as amended)

The Act of 5 June 1998 on Voivodship Self-government (uniform text Journal of Laws of 2001 No. 142, Item 1590)

The Act of 5 June 1998 on County Self-government (uniform text Journal of Laws of 2001 No. 142 Item 1592)

4 The European Charter of Local Self-Government drawn up in Strasbourg on 15 October 1985 was adopted in full by Poland, Journal of Laws of 25 November 1994 No. 124 Item 607.

${ }^{5}$ In the original text the author states why he used the term the European Charter of Territorial Self-Government in the original, Polish text, instead of the European Charter of Local Self-Government, explaining that the former results from the Polish tradition of self-governance and that the Polish state ratified the charter as such. However, the above explanation cannot be applied to the translation since the official English name of the charter uses the word 'local'. Whenever there is a reference to the territorial self-government in the Polish text, and English equivalent local self-government will be used (translator's note).

${ }^{6}$ At the time of ratification of the ECLSG, Poland was already the $18^{\text {th }}$ state which had adopted the convention.

See: A Government statement of 14 July 1994 on the ratification of the European Charter of Local Self-Government by the Republic of Poland, drawn up in Strasbourg on 15 October 1985 Journal of Laws No. 124, Item 608.
} 
of the state, moreover, without keeping appropriate public consultation procedure, without reflection on the good of the local communities and the society as a whole, but being deliberately calculated for little political yields. Thus, I claim that there should be as much analysis, discussion and suggestions in order to come to appropriate and acceptable solutions which would either be implemented or at least would become a model operating in the conscious society and would hinder all the irresponsible political behaviour described above. Furthermore, anyone who tries to spoil the appropriate order of things for expediency would have to take into consideration that the society will expect them to account for not respecting the socially acceptable models of functioning of the state structures and its governance system.

\section{What are the risks?}

The aforementioned competence chaos is one of the risks which may occur, as it took place after the hastily created amendment introducing the direct elections of commune heads, mayors and presidents, when lack of imagination, not to say lack of knowledge and skills, and due diligence in the preparation of the act could be observed. Even the lofty and socially acceptable solutions should be prepared with due diligence. Legal loopholes, conflicts of competence between various public administration bodies or ones without any assigned competences, or mentioning in numerous legal acts some public bodies which had already not existed at that time, what is more, with certain powers assigned to them.

The increase of the role and competence of the provincial self-government, as announced by some politicians, together with the exercise of their supervisory functions with regard to the other local self-governments may not only become the cause of numerous conflicts, but also the removal of their independence and the still clear three-tier division of state. The supervisory and control functions are traditionally and, as it may be observed in the democratic states, commonly attributed to the state authority which is locally exercised by its agents: territorial ministers, governors, prefects, province governors etc. supported by the independent centralized institutions such as The Supreme Audit Office or regional or even local ones such as Regional Chamber of Audit and self-government boards of appeal. Attributing the control function to any of the local self-government forms in relation to other units of local self-government will mean their end.

Another absurd idea (some add that it is German style which makes it even more absurd) of changing the Parliament's Upper House into a Local Self-Government 
Chamber. I would not argue with that opinion, since it would require a longer disquisition which due to the planned length of this article cannot take place and should be made into another one or at least a discussion. However, what is more important, it would be inappropriate due to the respect for the achievements and traditions of the Polish Senate. I would like to merely mention that there is a significant difference between the states forming a federation and a unitarian state forming the units of the local self-government in the spirit of the idea of subsidiarity, also on the regional level, as a result of its basic internal administrative subdivision of the state. The executive nature of the local self-governments should be a crucial element while assigning powers to them, particularly on the regional level. The supervision and control is and should be the domain of the state and its representatives, as well as independent institutions which were established for that purpose by the state.

Excessive and indiscriminate definition of competences of the provincial self-government together with more and more dynamic development of the EU regional policy may lead to a sort of "regional disintegration" of the country. We have already learned that lesson. Of course it will not happen overnight, however such understanding of regionalism has many supporters in many countries and is one of the trends of the EU regional policy. What needs to be stressed is also the fact that the aforementioned trend has also many opponents. However, the aim of this part of my considerations is to draw the attention to the possible risks which in some circumstances may become more or less real. Beyond any doubt, any ill-considered solutions may enable or even cause numerous conflicts and much unnecessary confusion, to the detriment of the social mission of the public administration.

Regardless of the solutions which will be recognized by the legislator, it is worth discussing the problem of the shape, competence, tasks and structures of public administration in Poland, as well as the view of the administrative map of the country. Such a discussion should start from the consideration of philosophy and the idea of it's functioning, in order not to let it be pushed into the coarseness and mundaneness of the political games which without doubt will occur at the end of the legislative process. Creation of the basis for the discussion - studies, analyses and suggesting the solutions should become a goal of science, so that politicians had a variety of choice during the legislative process. 


\section{What ideas should lie behind the change?}

One of the basic principles of the organization and functioning of public institutions in the European Union is the idea of subsidiarity ${ }^{7}$ In the encyclical Quadragesimo anno pope Pius XI summarises the ideal of subsidiarity as follows: "it is an injustice and at the same time a grave evil and disturbance of right order to assign to a greater and higher association what lesser and subordinate organizations can do. For every social activity ought of its very nature to furnish help (subsidium) to the members of the body social, and never destroy and absorb them. ${ }^{8}$ According to the principle of subsidiarity regions should deal with what exceeds the capabilities of local authorities - the strategic planning in particular? Each "higher" level of public administration, regardless whether state or municipal, also regardless of the reason why it stands"higher", should always deal only with what is not possible to realize at the "lower" level or in the smaller structure or what would occur irrational to realize due to various reasons (e.g. too high costs or too few interested entities, etc.).

M. Kulesza believed that the principle of subsidiarity requires the government to delegate as broad public tasks as possible to the citizens and self-government communities. Therefore, the idea of centralism is juxtaposed with the social activity on the regional and local level. ${ }^{10}$

"One of the fundamental elements of the changes with regard to the reform of the public administration was shaping the new territorial division of the country, as part of which the reform aims could be realized concerning: the increase of effectiveness and efficiency of the public administration offices, realization of public services and public finance management on the regional and local level. The new territorial division of the country was supposed to define sufficiently

\footnotetext{
${ }^{7}$ In the Republic of Poland the principle of subsidiarity is a principle of constitutional law: We, the Polish Nation [...]Hereby establish this Constitution of the Republic of Poland as the basic law for the State, based on respect for freedom and justice, cooperation between the public powers, social dialogue as well as on the principle of subsidiarity in the strengthening the powers of citizens and their communities. The Constitution of the Republic of Poland of 2 April 1997 (Journal of Laws No. 78, Item 483), a fragment of the preamble.

8 His Holiness Pius XI "Quadragesimo Anno", ("An encyclical Letter on Reconstructing the Social Order and Perfecting it Conformably to the Precepts of the Gospel"), part 79, Documents of the Catholic social science, part I, p. 85.

9 T. Sowiński, "Regiony w wybranych państwach członkowskich Unii Europejskiej” [in] Regiony Acquis communautaire, edited by Z. Brodecki, Wydawnictwo Prawnicze LexisNexis, Warsaw 2005, p. 70.

${ }^{10}$ M. Kulesza, "Droga do Polski prawdziwej", [in:] Podstawy reformy samorządowej, E. Toczyska (ed.), Akademicki Ośrodek Edukacji Samorządowej Uniwersytetu Gdańśkiego, Gdańsk 1998, p. 9.
} 
homogeneous fields of activity for the majority of public administration offices of each level operating throughout the country and also guarantee the necessary number of the state's administrative structures which are aimed at creating more transparent and more accessible for the citizens system of the public administration units and institutions. ${ }^{11}$

These were the ideas and practical assumptions which, in the socio-historical aspect, determined the restoration of districts as civic communities, the public service system and new strong provinces with strong position of the province governor and provincial self-government pursuing socio-economic and cultural policies. $^{12}$

The transformation started with establishing the real self-government in $1990^{13}$, on the commune level, which became a test ground for various legal, structural and jurisdictional solutions, and also rules and methods of financing the public tasks carried out by the self-government, its status and participation in the public finance system and solving problems resulting from its diversity ${ }^{14}$.

Young Polish democracy ${ }^{15}$, during almost every legislative period, underwent shifts from one ideological extreme to another with regard to the views on the ways

11 Reforma Administacji Publicznej 1998-2001, J. Płoskonka (ed.), Ministerstwo Spraw Wewnętrznych i Administracji, Warsaw 2001, p. 25.

12 M. Kulesza, "Droga..., op. cit., p. 9.

13 Two Acts were of key importance during the process: The Act of 8 March 1990 on the Local Government (see footnote 1); and The Act of 17 May 1990 on division of tasks and jurisdiction stipulated by special acts between the organs of the commune and the organs of government administration and on the amendments to some acts (Journal of Laws No. 34, Item 198, as amended), see also footnote 2 .

14 For example: The Act of 20 December 1996 on communal services (Journal Of Laws of 1997 No. 9, Item 43, as amended); The Act of 8 August 1996 on the rules for exercising the rights the State Treasury is entitled to (Journal Of Laws of 1996 No. 106, Item 493, as amended); also: The Decree of the Minister of Finance of 23 July 2008 of the Minister of Finance, on Classification of Incomes and Expenses, Revenues and Expenditures,. (Journal of Laws No. 59, Item 688, as amended); The Decree of 29 December 2000 on detailed principles of financial management of the budgetary entities, budgetary enterprises and auxiliary facilities of the budgetary entities, detailed principles and due dates of annual accounts and budget contributions made by the budgetary enterprises and the auxiliary facilities of the budgetary entities (Journal of Laws No. 122, Item 1333).

15 Tradition of Polish parliamentarism and the democratic form of governance in Poland have one of the longest history among the European countries, however being shamefully betrayed and handed over to the "sphere of influence" of the Soviet Union, Poland along with Czech Republic, Slovakia, Hungary and other countries of the so called Eastern Europe were sold for the price of peace and prosperity in the Western countries. Not until 1989 did Poland regain its full sovereignty, which meant that Poland had been under police and military dependence from foreign states for fifty years. The phrase "young Polish democracy" was used, because Poland, at that time, also started building from scratch its democratic structures of the rule of law. 
of organisation of the state, territorial structure, number and scope of jurisdiction of particular types of the local self-government, but also such fundamental issues as: administrative division of the state, scope of tasks and role of the state administration. Such state of affairs was supported by the socio-political circumstances of the system transformation which was unquestionably necessary, however its form and scope underwent continuous changes. This is reflected, among others, in the regualtions of the Constitution of the Republic of Poland which had to become a far-reaching compromise, and thus a very imprecise legal provision.

The commune (gmina) shall be the basic unit of local government. Other units of regional and/or local government shall be specified by statute. ${ }^{16}$ In the provision cited, the legislator sanctions the dominant position of the commune among other projected units of local government. It seems obvious for at least two reasons:

1. The commune is a unit which was proven in action and there is no doubt about the validity of its existence, and there was also a broad agreement on that issue.

2. The commune is the primary entity of local government administration where citizens settle most of the matters that concern them. It is also their nearest authority with which the citizen has anything to do and which exists in almost every country, yet in different forms ${ }^{17}$.

The case of the commune does not evoke any serious problems with interpretation, however how should the other units of regional or regional and local government be understood, which according to the provision cited above shall be specified by statute? The main contested issue was the question of reintroduction of districts. The number of districts, as well as the number of provinces, was of secondary importance. It was for the reason of validity of reintroduction of districts that the statement concerning the districts was eventually not included expressis verbis in the content of the constitutional provisions. Instead, an enigmatic statement on the possibility of establishment of the local government was included. The contention about the districts and provinces contributed to strengthening the legal position of the commune. Generally, such solution is rather good. It

\footnotetext{
16 Article 164, points 1 and 2, The Constitution of the Republic of Poland of 2 APRIL, 1997 (Journal of Laws No. 78, Item 483),

17 There are various names for this type of local government unit (e.g. commune, municipality, parish, local community, etc.), yet almost everywhere they play a similar role of a body of public administration which is the closest to the citizens, and settling most of the matters concerning them. See e.g.: I. Pietrzyk, Polityka regionalna Unii Europejskiej i regiony w Państwach Członkowskich, WN PWN, Warsaw 2001, pp. 72 and 73; T. Sowiński, "Polityka regionalna Unii Europejskiej. Wybrane zafadnienia”. Studia Gdańskie, Wizje i rzeczywistość, vol. III, Wydawnictwo Gdańskiej Wyższej Szkoły Humanistycznej, Gdańsk 2006, p.37.
} 
is the commune which has to deal with most of the tasks and responsibilities, and at the same time whatever direction might the discussion take, the option without the commune, with most of its current competences, seems almost impossible. Moreover, if the commune is successful in exercising its competencies, what would be the reason for shifting them onto another entity. It would be contrary to the constitutional principle of subsidiarity.

It is also worth considering the position and necessity of keeping the districts and provinces as a part of the structures of regional self-government. The most animated dispute flared about the districts. It concerned the number, tasks, structure, purpose and reason for introducing such entity. In the majority of cases, the discussion on the institution of districts was burdened with a fundamental logical error, namely isolating them from other entities of public administration and analysing their tasks and planned competencies as a unit of self-government in isolation from other tasks planned for them, e.g. those delegated by the state administration. The problem of districts cannot be processed without taking into account their role and tasks along with the roles and tasks of local and provincial self-governments. Furthermore, what also needs to be taken into account are the expectations with regard to the introduction of districts, especially about the property management, especially the property of the State Treasury, as well as their role in building the structures related to the security of people ${ }^{18}$.

There is a category of tasks of a district which is of special importance ${ }^{19}$, namely "ensuring the realization of tasks and powers for the managers of district services, inspections and guards, as provided in the statutes" ${ }^{20}$

In accordance with article 35(2) of the Act of 5 June 1998 on the district self-government, the district combined administration is under the authority of the district governor, within the tasks delegated by the central administration ${ }^{21}$.

18 T. Sowiński, "Silne regiony czy rachityczne województwa? Uwagi nad dokończeniem reform administracyjnych”, Studia Gdańskie i rzeczywistość, vol. V, Wydawnictwo Gdańskiej Wyższej Szkoły Humanistycznej, Gdańsk 2008, pp. 213 and 214.

19 The issue is considered further by M. Stec, Służby, inspekcje i straże w nowym ustroju administracyjnym, "Samorząd Terytorialny" no. 12, 1998.

${ }^{20}$ Article 4(2) of the Act of 5 June 1998 on the District Self-government, uniform text (Journal of Laws of 2001, No. 142, Item 1592, as amended).

${ }^{21}$ District Inspector of Building Control - the authority supervising the observance of the administrative construction law, the District Police Commander, District Fire Commander, National District Sanitary Inspector and District Veterinary Officer, and in the following year also the District Employment Office, were entrusted to the authority of the district governor. 
Unfortunately, the legal nature which was originally given to those institutions ${ }^{22}$, was changed over time and some of these tasks were removed from the competence of a district governor. It resulted in unnecessary complication of the decision making structures. Despite their renationalisation which was to simplify the decision making, in practice it occurred counter-productive. Starting with the public order and finishing with the unemployment prevention and health care provision in the residential health care facilities.

In this overall context the need for the establishment of districts seems much more reasonable. The idea is supported by the principle of subsidiarity, which was expressed earlier, according to which the social order should be built as a necessity of retaining tasks and competences on such level of social life structure on which they can be realized. Not higher and not lower.

According to such assumptions, there should be at least three types of local self-government in a country similar to Poland:

1. basic, which is the closest to the local community and meets its basic needs through the realization of the fundamental scope of the local authorities' duties and tasks;

2. Middle-level, on which tasks of supra-communal, local character are realized and which would occur ineffective or would involve considerable and disproportionate expenses to the provided services, if realized on the level of each commune, especially those incurred from public funds. In spite of different perspective from which the principle of subsidiarity is viewed on by the regional self-government, the conclusions remain the same, namely they confirm the validity of the existence of districts. Realization of particular local tasks (supra-communal) on the regional level would be ineffective due to too high costs incurred by the citizens. Moreover, too far distance from the institutions providing certain services to the residents would be another problem, but also the pointlessness of such solution results from:

- the lack of indispensability for assuming certain tasks by the regional self-government due to the fact that the local self-government may and should manage the tasks on its own and

- the lack of indispensability for assuming certain tasks by the regional self-government, because it is established for different reasons and to realize different tasks. Therefore, realization of the tasks of the local self-government by the regional self-government not only would be contrary to the principle

${ }^{22}$ H. Izdebski, Samorząd terytorialny. Podstawy ustroju i działalności. Warsaw 2003, p. 99. 
of subsidiarity, but also would hinder the proper realization of its own tasks, for which it was established.

It must not be forgotten, that the aforementioned needs of the central administration which delegates some of its tasks and competences to the local (district) self-government as the most appropriate entity with regard to its aims, character and territory where it is located. Realization of some tasks reserved for the central authorities by themselves would be more ineffective than their realization by the regional authorities. Delegating chosen tasks to the local authorities is a much better, socially acceptable and less expensive formula of their realization. It is also appropriate to state that even if there was not any local self-government of the middle level, other structures of central administration would have to be established, as it used to be, e.g. District Offices with managers appointed by the province governor.

3. regional, which fundamental aim is strategic planning, coordination of activities of supra-local character, economic development, compensatory adjustment of the regional level, supporting the local and middle-level self-governments. The problem of the status, competence and structure of the regions (provinces) was solved in Poland relatively clearly ${ }^{23}$, whereas the general relationship between the state and the region is primarily a result of the specificity of the state and its political system ${ }^{24}$. It is also worth mentioning an element which is rarely taken into consideration and which, in my opinion, may become in the future one of the most important, if not the most important reason for the existence of the regional self-government, namely the readiness but also the ability to overtake and effectively realize as many tasks from the central level as possible, especially those of the executive character. There is absolutely no reason which is rational, logical and consistent with the spirit of the principle of subsidiarity for

\footnotetext{
${ }^{23}$ T. Sowiński, Polityka regionalna Unii Europejskiej. Wybrane zafadnienia (część 2 - regiony), Studia Gdańskie, Wizje i rzeczywistość, vol. IV, Wydawnictwo Gdańskiej Wyższej Szkoły Humanistycznej, Gdańsk 2007, p.66.

${ }^{24}$ T. Sowiński, Regiony w wybranych relacjach funkcjonalnych [in] Regiony Acquis communautaire, [ed.] Zdzisław Brodecki, Wydawnictwo Prawnicze LexisNexis, Warsaw 2005, p. 66.
} 
which the majority of executive functions and tasks in the state would not possible to realize by self-government ${ }^{25}$, what seems to be confirmed by the previous experiences $^{26}$.

Is the fourth and further types (levels) of self-government needed?

It seems that it is not necessary in a country similar to Poland in size, political system, traditions and structure. It is however possible to implement other divisions for specific aims, not necessarily related to public administration. For example, there are eight economic centres (districts), two military districts, two inland water catchment areas divided into seven regional boards of water management, four tax zones for the purposes of the agricultural tax and many other divisions resulting from the specificity of the areas of social and economic life. The three-tiered division of the local self-government seems to be optimal and justified in the Polish specificity and tradition.

\section{Financing of the local self-government}

Basic principles for the financing of the local self-government may be derived from article 9 of the ECLSG ${ }^{27}$. Taking into account the fact that the Charter was ratified by Poland, it seems obligatory to recognize that the Charter has become de facto and de jure an internal element of Polish law. Therefore, which criteria should be met to ensure the funds for the functioning of the local self-government, especially for realization of the tasks assigned to them?

"1. Local authorities shall be entitled, within national economic policy, to adequate financial resources of their own, of which they may dispose freely within the framework of their powers.

\footnotetext{
${ }^{25}$ The biggest obstacle in the realization of such vision of the state is the oligarchy of middle and senior managerial officials of the central administration who are able to torpedo any lofty idea which could be beneficial for the state and the society when fighting for their "dominion," their own interests or positions. The inter-ministerial consultations may become a measure to ruin and bury every change, even the most obvious one, providing it will not be in favour of the aforementioned group.

Undoubtedly, one of the reasons for such state of the matters is lack of the real civil service which would be a group of professional, highly-qualified personnel of public administration who would be conscious of their social mission and working with due diligence and commitment for the good of the State, the society and self-government community. It is one of the greatest failures of public administration after 1989. The residual formation of the civil service will not change this state of the matter.

26 T. Sowiński, "Silne regiony..., op. cit., p. 217.

27 Article 9 of the ECLSG "Financial resources of local authorities".
} 
2. Local authorities' financial resources shall be commensurate with the responsibilities provided for by the constitution and the law.

3. Part at least of the financial resources of local authorities shall derive from local taxes and charges of which, within the limits of statute, they have the power to determine the rate.

4. The financial systems on which resources available to local authorities are based shall be of a sufficiently diversified and buoyant nature to enable them to keep pace as far as practically possible with the real evolution of the cost of carrying out their tasks.

5. The protection of financially weaker local authorities calls for the institution of financial equalisation procedures or equivalent measures which are designed to correct the effects of the unequal distribution of potential sources of finance and of the financial burden they must support. Such procedures or measures shall not diminish the discretion local authorities may exercise within their own sphere of responsibility.

6. Local authorities shall be consulted, in an appropriate manner, on the way in which redistributed resources are to be allocated to them.

7. As far as possible, grants to local authorities shall not be earmarked for the financing of specific projects. The provision of grants shall not remove the basic freedom of local authorities to exercise policy discretion within their own jurisdiction.

8. For the purpose of borrowing for capital investment, local authorities shall have access to the national capital market within the limits of the law".

Having read the content of article 9 of the ECLSG which defines the source, rules for creating and using the financial resources of the local authorities, it may be stated that they are almost obvious and basically indisputable. It is worth, however, mentioning that in October 1985 they did not seem so natural as today. For many states they sounded almost revolutionary. The provisions of this article shattered the structures of the state, rules for its functioning and sometimes even certain traditions. It is reflected in the fact that many states ratified the ECLSG with numerous reservations, including those concerning the way of financing od the local self-government.

In reference to the current legal solutions in Poland, it may be stated that, doubtlessly, practically all points of article 9 of the ECLSG are being realized, although the way of their realization is often controversial. It also happens that the state 
is so scrupulous in realizing the provisions, that it arises the local authorities' protests. Let me use the example of so-called "Janosikowe" (a form of special tax that is paid by wealthier municipalities in Poland and redistributed among poorer ones [translator's note]) which undoubtedly constitutes the realization of the provision from paragraph 5, however the State wants to protect the financially weaker local authorities so much, that it introduced the financial equalisation procedures in order to correct the effects of the unequal distribution of potential sources of finance and of the financial burden they must support, that it actually "robs" the financially stronger communities, moreover, in a sort of controversial way ${ }^{28}$.

The realization of two other paragraphs, namely paragraph 2 and 6, is also controversial. On one hand, the obligation to provide funds for the local self-government commensurate with the responsibilities provided for by the constitution and the law is observed, and in accordance with paragraph 2 , even the very provisions are included in the constitution and other acts indicated in it. On the other hand, the way of interpretation of certain provisions, especially the notion of adequacy in its practical terms raises some doubts. Furthermore, the implementation, or rather not implementation, of paragraph 6 leaves a lot to be desired. All kinds of consultations, not only those concerning financing, generally may be described as ineffective.

Public duties aimed at satisfying the needs of a self-governing community shall be performed by all units of local self-government as their direct responsibility. However, in duly substantiated needs of the state, other public duties may be delegated to some units of a local self-government by legislation. Simultaneously, the procedure and the way of realization of the delegated tasks shall be precisely specified $^{29}$.

What is essential is that the units of the local government shall be assured public funds adequate for the performance of the duties assigned to them. The revenues of units of local self-government shall consist of their own revenues as well as general subsidies and specific grants from the State Budget, and their sources are prescribed by the law. However, what needs to be mentioned is that for some time already difficult, unrewarding and underfunded tasks are delegated to the local authorities. Moreover, the tasks mentioned are usually badly graded either by

\footnotetext{
${ }^{28}$ For more information see: "Finansowanie jednostek samorządu terytorialnego - wybrane problemy", [in:] Finanse samorządowe po 25 latach samorządności. Diagnoza i perspektywy. W. M. Miemiec [ed.], Wolters Kluwer monographies, Warsaw 2015, pp. 228-237.

29 T. Sowiński, Prawo budżetowe samorzadu terytorialnego (in:) Podstawy finansów i prawa finansowego, edited by A. Drwiłło, Warsaw 2014, p. 563.
} 
the society and/or by other official bodies such as Supreme Chamber of Control. Central administration delegates the tasks with the belief that local authorities will "add the lacking resources", which means clearly that the delegated tasks are financially undervalued. Therefore, the way to properly execute these tasks is, de facto, assign the additional tasks to the particular units of the local self-government with insufficient funds, very often far too insufficient, to adequately fulfil them. This means that the state transfers its deficit tasks to local authorities in expectation that in order to fulfil them properly, they will add their own resources. Consequently, this is what very often happens. However, local authorities transfer the lacking funds to the detriment of the local communities since the money they spend on the additional tasks cannot be used for realizing their own aims, hence satisfying the basic needs of the local communities. Therefore, such is the basic weakness of the activity of the state which abuses its powers and charges local authorities with additional tasks without allocating sufficient funds. It is contrary to the act on public finance, as well as to other acts concerning the rules of financing the units of the local self-government, but most of all with the provisions of the Polish Constitution which unambiguously obligates the state to delegate the tasks to the local self-governments with allocating sufficient funds for their fulfilment ${ }^{30}$. Unfortunately, such remarks are applicable also to other activities of the state with regard to the local self-government communities ${ }^{31}$. For central government such a solution is almost perfect. It gets rid of the unwanted and onerous tasks which execution is often criticized, and what is more, it often gains financially on such delegation by not having to contribute financially to it. How do the local authorities react? They protest, appeal to courts, to the Constitutional Tribunal but eventually fulfil the tasks assigned to them and add the lacking funds by depleting their own spare resources, which should serve the development of local community by improving the infrastructure and citizens' comfort of life or improving the quality of public utility services ${ }^{32}$.

Nevertheless, regardless of the above remarks concerning the adequacy of the allocated resources and also some solutions regarding certain forms

\footnotetext{
${ }^{30}$ Article 167(4) of the Constitution of the Republic of Poland. Alterations to the scope of duties and authorities of units of local government shall be made in conjunction with appropriate alterations to their share of public revenues.

31 T. Sowiński, Praktyki przekazywania i określania zasad wykonywania zadań oraz środków finansowych na ich wykonanie jednostkom samorządu terytorialnego na wybranych przykładach (in:) J. Gliniecka, E. Juchniewicz, T. Sowiński, M. Wróblewska (ed.), Prawo finansowe samorządu terytorialnego. Prawo finansowe wobec wyzwań XXI wieku, Warsaw 2013, p. 236.

32 T Sowiński, Finansowanie..., op. cit., p. 235.
} 
of financing or financial support of units of local self-government, it needs to be stated that Poland is not only one of the most municipalized countries in Europe, but also fulfils the provisions of ECLSG with regard to financing the tasks of units of self-government.

\section{The supervision of local self-government}

In order to explain the essence of local self-government it is also necessary to explanain of the essence of the supervision of local self-government ${ }^{33}$. Primarily, it requires to define the supervising entity and its powers ${ }^{34}$. The supervision of local self-government cannot be claimed contrary, as one might think, to the autonomy of these authorities. The involvement of supervisors seems justified, especially when units of local self-government act against the law. Therefore, one of the fundamental criteria of the activity of the self-government should be the criterion of legality ${ }^{35}$.

Poland is one of the few European Union countries, but also the whole Europe, which has implemented the provisions of the European Charter of Local Self-Government to such a great extent ${ }^{36}$. There are frequent accusations, especially form the self-governmental environment, concerning the allegedly small autonomy of local self-government in Poland. However, there are very few countries in Europe where the local self-government units have broader powers and more transparent and coherent structure. It does not mean, of course, that the ideal has been reached, nevertheless, we have gone further in terms of building a strong local government than most European countries. A symbolic and meaningful proof for such state of affairs is the fact that the Republic of Poland ratified the whole ECLSG without reservations.

33 J. Granowski, konstytucyjne podstawy nadzoru państwa nad samorządem terytorialnym, „Samorząd Miejski” no. 18/1930; C. Wienner, Władza centralna i władza lokalna - mity i rzeczywistość. Kontrola, czy rzeczywistość, [in:] J. Łętowski [ed.] Administracja Republiki Francuskiej, Ossolineum 1984, pp. 157-158.

${ }_{34}$ A.Drwiło, J. Gliniecka, L.Lamenta, J. Wójcik:,System dochodów samorządu terytorialnego”, Sopot 1993,p.19.

${ }^{35}$ K. Nowacki, funkcjonowanie administracji publicznej w Austrii i kontrola przepisów administracyjnych (na tle problematyki ochrony środowiska), [in:] Acta Universitatis Wratislaviensis no. 922, Wrocław 1988, p. 153.

36 The European Charter of Local Self-Government was drawn up in Strasbourg on 15 October 1985 and was ratified by Poland as a whole, Journal of Laws of 25 November 1994, No. 124, Item 607. 
"Local government shall perform public tasks not reserved by the Constitution or statutes to the organs of other public authorities". ${ }^{37}$ A contrario, one could state that the provision implicates that all public tasks which were not reserved by legislation to central administration offices or other bodies of public authorities, such as public prosecutor, supervisory body and others, are in fact reserved to the local self-government. Thus, even without completing the list of the self-govenment's tasks, but only with reducing the number of the other public authorities' tasks, it is possible to change essentially the scope of powers of the local self-government. Such a solution is, however, contrary to the principle of completeness and complementarity in law-making. The legislator cannot allow a situation when tasks and scopes of powers are not assigned expressis verbis to any of the public authorities, not mentioning that the assignment ought to be accurate. However, it is crucial to appropriately balance the distribution of responsibilities and public tasks. At least the discussion on the division of the scope of powers should take place in an atmosphere of partnership and equality of the parties: the central government and the local self-government. Furthermore, in the course of discussion on the aforementioned subject another party should take part making a kind of trilateral commission, namely the group of experts which would comprise, first of all, of the representatives of science, who deal with the problem of the political system and the local self-government, but also administration and public finance sector officers, economists and representatives of non-governmental organisations.

In order to fulfil the provision of the constitutional principle of subsidiarity in practice, the public task assignment to the local self-government ought to be as broad as possible. The government party should, in turn, rather justify the decision of keeping some tasks in its own jurisdiction, than assigning certain tasks to the local self-government. Such a broad amendment in the scope of tasks should involve at least two other changes. One of them should be radical strengthening of the position of the province governor as a representative of the government authority who is responsible for public safety, but also, what seems even more important, for the supervision of the appropriate, in legal terms, realization of the local self-government's tasks. The other change ought to involve a radical reduction in the number of provinces to allow them to become really

37 Article 163, The Constitution of the Republic of Poland of 2 April 1997 (Journal of Laws No. 78, Item 483), 
strong and self-sufficient regions, also in financial terms ${ }^{38}$. M. Kulesza believed that the only reason for the existence of the regional self-government, the provincial self-government is boosting the economic development. He believed that regions should boost the economic development by shaping the competitive localisation of a particular region with regard to other regions in the country and abroad ${ }^{39}$. Strengthening the provincial self-government makes no sense if it is supposed to be represented by small, weak and poor pseudo regions which cannot even dream of being self-sufficient, not mentioning being competitive with the regions of the developed Member States of the European Union. It may be brought down to a quid pro quo formula, but what is, however, much more important is the understanding that strong regions are supposed to form a strong state rather than live on its expense and be dependant on its help. The changes described are not only a reform of local self-government - they are the reform of the state and its good and the good of the whole society must be the highest priority for the authorities of all levels, not the local interests or ambitions. It must be remembered that the Republic of Poland is a unitary state and as such it should remain, establishing strong local self-government in accordance to the principle of subsidiarity rather than internal competitiveness.

\section{Concluding remarks}

Practical realization of the principle of subsidiarity which assumes that public tasks should be entrusted to the local community of the lower level and its units and companies should perform as many tasks as they are able to perform efficiently and effectivel $y^{40}$. Thus, the principle of subsidiarity should be realized through:

\section{1. the state:}

a) the preservation of strategic and constitutional competences of the central authorities only, and only those which cover the whole country (it will

\footnotetext{
${ }^{38}$ For example in the ongoing discussion on introduction of several competing regional healthcare funds instead of a central one, it is indicated that one fund would comprise several provinces. What seems a much better idea is the reduction of the number of provinces to $8-10$ and then create provincial (regional) healthcare funds which would cooperate with a particular provincial self-government. Naturally, there are a lot of similar examples confirming the appropriateness of such a solution.

${ }_{39}$ M. Kulesza, Wspólnota samorządowa jako główny czynnik decentralizacji państwa, W Ruchu, Nr 5(22), 2002, p. 4.

${ }^{40}$ A. Borodo, „Samorząd terytorialny. System prawnofinasowy", WP LexisNexis, 3rd revised edition, Warsaw 2004, p. 18.
} 
undoubtedly meet resistance from the so-called centre, especially the central administration officials).

b) the preservation by the Government and provincial governors of the supervision and control over the correctness of the execution of law by the local authorities with the possibility of occasional interference into their supervisory and compensatory decisions (the latter ones will not be received with enthusiasm of local authorities)

c) assigning the largest possible number of tasks and powers to the local and regional self-government, but also proportional increasing legal and political responsibility of the local authorities, followed by the broadening the supervisory and control powers of the departments of governmental administration.

d) liquidation of so-called "middle" central administration and devolution of governmental tasks which would involve the removal of the dual power system and the conflict of competence and responsibility between the province governors and national (state, general, central) inspectors (conservators, fire brigade/military chiefs, etc.). It would involve the change of the operating philosophy and central administrative structures.

\section{Province}

\section{“self-governmental"}

a) increasing the role of the region through:

- reduction of the number of provinces to 8-10,

- broadening the scope of powers of the provincial self-government,

- strengthening the position of the province marshal as a real host of the region,

- direct elections of the province marshals,

b) the province marshals convention as a regular advisory body of the Prime Minister. It would obligatorily formulate opinions on any legal proposals concerning self-government,

c) indication of the exclusive and self-sufficient governance of the region in chosen fields with regard to the use of the EU funds, - decentralisation,

\section{“governmental"}

a) strengthening of the position and role of provincial governors in the system of internal security of the state, as a real head of the guard and state inspectors - including the police, combined and non-combined administration - this would mean creation of a cohesive and effective system of central 
administration in the region, instead of the hitherto existing conglomerate of independent and often disorderly services - deconcentration,

b) depriving the provincial governor of any attributes of the executive power, including the role of intermediary in the transfer of the governmental and central resources. It should change the unhealthy situation of disputes between government departments, provincial governors and authorities of local self-government and what is more, strengthen the ministerial responsibility for the relationship with the local government and (maybe) persuade them to transfer more powers on the local self-government.

\section{Disctrict}

a) restoration and strengthening of the role of the district through:

- restoration of powers and tasks which were originally planned but eventually taken away during the term of office 2001-2005,

- direct elections of the district governors;

b) districts should be the third element of the widely understood national security system

- basing the structures of the guards and inspection, civil defence, (possibly the National Guard), medical safety (emergency), and so forth on the district as the first level (not necessarily the lowest).

\section{Commune}

The commune is and will remain the constitutional (so far - the only) level of the local self-government, and what is more, the most important, since it is the closest and deals with the most matters concerning the citizens, residents.

To make things simple, one could summarize the remarks by defining expressly the character of the basic tasks of particular self-government communities as:

- Province - strategy and the absorption of aid measures,

- district - security, complementation of the central administration tasks and so-called mid-level infrastructure.

- commune - basic (and the most numerous) tasks associated with the role of the host of the primary self-government community,

Definitely, it is appropriate to strive to preserve the independence of local self-government communities, also in the mutual relationships. Strengthening of the role of the province marshal cannot mean his control over other 
communities! The dominant role of a province marshal should be associated with his or her authentic personal authority rather than the formal one.

Any supervisory functions and controls should remain in the hands of central administration and the independent institutions, of course the ones that already exist, such as The Supreme Audit Office or Regional Chamber of Auditors. There is no justification for the appointment of any new entities for this purpose.

It seems reasonable, except for some immediate changes, to perform an extensive review of the current state, functioning and law concerning the widely understood public administration. This should be followed by a project of a reform of the public administration, possibly in the spirit of the above remarks, which would finally close its shaping process for a long time and let its structures consolidate. Furthermore, citizens would also have an opportunity to accept and get used to such a model of central and local administration. The crowning achievement of the reform would be the creation of a professional, apolitical and multi-level civil service.

In spite of the obviousness of the following remark, I will allow myself to utter it. I would like to remind that public administration likewise the state in which it operates is a unity. Moreover, the law and its principles are also uniform. Above all, however, the society is a sovereign for which central and local public administration were established, in order to serve it in a harmonious and cooperative way ${ }^{41}$.

Incessant reminding of the above finding and presenting it as motto of functioning of public administration, but also its aim and the way of achieving it, seems not only justified but also necessary and essential for its proper functioning and effective service to the society.

\section{Bibliography}

A. Borodo, „Samorząd terytorialny. System prawnofinansowy”, WP LexisNexis, $3^{\text {rd }}$ revised edition, Warsaw 2004.

Z. Brodecki, Regiony Acquis communautaire, Wydawnictwo Prawnicze LexisNexis, Warsaw 2005.

A.Drwiło, J.Gliniecka, L.Lamenta, J.Wójcik: „System dochodów samorządu terytorialnego", Sopot 1993.

${ }_{41}$ T. Sowiński, "Silne regiony..., op. cit., p. 222. 
The European Charter of Local Self-Government, drawn up in Strasbourg on 15 October 1985 and ratified by Poland as a whole, Journal of Laws of 25 November 1994, No. 124, Item 607.

J. Granowski, Konstytucyjne podstawy nadzoru państwa nad samorządem terytorialnym, „Samorząd Miejski” no. 18/1930.

H. Izdebski, Samorząd terytorialny. Podstawy ustroju i działalności. Warsaw 2003.

The constitution of the Republic of Poland (Journal of Laws No. 78, item 483),

M. Kulesza, Wspólnota samorządowa jako główny czynnik decentralizacji państwa, W Ruchu, No. 5(22), 2002.

M. Kulesza, "Droga do Polski prawdziwej", [in:] Podstawy reformy samorządowej, E. Toczyska (ed.), Akademicki Ośrodek Edukacji Samorządowej Uniwersytetu Gdańśkiego, Gdańsk 1998.

M. Kulesza, Wspólnota samorządowa jako główny czynnik decentralizacji państwa, W Ruchu, No. 5(22), 2002.

K. Nowacki, funkcjonowanie administracji publicznej w Austrii i kontrola przepisów administracyjnych (na tle problematyki ochrony środowiska), [in:] Acta Universitatis Wratislaviensis no. 922, Wrocław 1988.

I. Pietrzyk, Polityka regionalna Unii Europejskiej i regiony w państwach członkowskich, Wydawnictwo Naukowe PWN, Warsaw 2001, p. 32.

A letter of 9 January 2008 issued by the Secretary of State in the Ministry of Internal Affairs and Administration Mr Thomas Siemoniak encouraging public consultation and proposing amendments of the planned reform of the public administration, DAP/72-11/08/AW.

His Holiness Pius XI „Quadragesimo Anno”, („An Encyclical Letter on Reconstructing the Social Order and Perfecting it Conformably to the Precepts of the Gospel") part 79, Documents of the Catholic social science, part I.

Reforma Administracji Publicznej 1998-2001, j. Płoskonka (ed.), Ministerstwo Spraw Wewnętrznych i Administracji, Warsaw 2001.

Sowiński T. "Finansowanie jednostek samorządu terytorialnego - wybrane problemy", [in:] Finanse samorządowe po 25 latach samorządności. Diagnoza i perspektywy. W. M. Miemiec [ed.], Wolters Kluwer monographies, Warsaw 2015.

Sowiński T., Prawo budżetowe samorządu terytorialnego (in:) Podstawy finansów i prawa finansowego, edited by A. Drwiłło, Warsaw 2014, p. 563.

Sowiński T., Praktyki przekazywania i określania zasad wykonywania zadań oraz środków finansowych na ich wykonanie jednostkom samorządu terytorialnego na wybranych przykładach (in:) J. Gliniecka, E. Juchniewicz, T. Sowiński, M. Wróblewska (ed.), Prawo finansowe samorządu terytorialnego. Prawo finansowe wobec wyzwań XXI wieku., Warsaw 2013.

Sowiński T., "Polityka regionalna Unii Europejskiej. Wybrane zagadnienia". Studia Gdańskie, Wizje i rzeczywistość, vol. III, Wydawnictwo Gdańskiej Wyższej Szkoły Humanistycznej, Gdańsk 2006. 
Sowiński T., Polityka regionalna Unii Europejskiej. Wybrane zagadnienia (część 2 regiony), Studia Gdańskie, Wizje i rzeczywistość, vol. IV, Wydawnictwo Gdańskiej Wyższej Szkoły Humanistycznej, Gdańsk 2007.

T. Sowiński, "Regiony w wybranych państwach członkowskich Unii Europejskiej" [in] Regiony Acquis communautaire, edited by Z. Brodecki, Wydawnictwo Prawnicze LexisNexis, Warsaw 2005.

Sowiński T., Regiony w wybranych relacjach funkcjonalnych [in] Regiony Acquis communautaire, [ed.] Zdzisław Brodecki, Wydawnictwo Prawnicze LexisNexis, Warsaw 2005.

Sowiński T., "Silne regiony czy rachityczne województwa? Uwagi nad dokończeniem reform administracyjnych", Studia Gdańskie i rzeczywistość, vol. V, Wydawnictwo Gdańskiej Wyższej Szkoły Humanistycznej, Gdańsk 2008.

Stec M., Służby, inspekcje i straże w nowym ustroju administracyjnym, "Samorząd Terytorialny" no 12, 1998.

Wienner C., Władza centralna i władza lokalna - mity i rzeczywistość. Kontrola, czy rzeczywistość, [in:] J. Łętowski [ed.] Administracja Republiki Francuskiej, Ossolineum 1984.

\section{Legislation}

The Constitution of the Republic of Poland of 2 April, 1997 (Journal of Laws No. 78, item 483),

Journal of Laws No. 124, Item 607 of 25 November 1994, The European Charter of Local Self-Government drawn up in Strasbourg on 15 October 1985, adopted by Poland in full.

The Act of 8 March 1990 on the Local Government (Journal of Laws of 1996 No. 13, item 274 , as amended)

The Act of 4 September 1997 on Branches of Government Administration (Journal of Laws No. 141, item 943, as amended)

The Act of 5 June 1998 on Voivodship Self-government (uniform text Journal Laws of 2001 No. 142, item 1590)

The Act of 5 June 1998 on County Self-government (uniform text Journal Laws of 2001 No. 142 item 1592)

The Act of 17 May 1990 on division of tasks and jurisdiction stipulated by special acts between the organs of the commune and the organs of government administration and on the amendments to some acts, Journal of Laws No. 34, Item 198, as amended.

The Act of 20 December 1996 on communal services (Journal Laws of 1997 No. 9, Item 43 , as amended).

The Act of 8 August 1996 on the rules for exercising the rights the State Treasury is entitled to (Journal Of Laws of 1996 No. 106, Item 493, as amended).

The Decree of the Minister of Finance of 23 July 2008 of the Minister of Finance, on Classification of Incomes and Expenses, Revenues and Expenditures,. (Journal of Laws No. 59, Item 688, as amended). 
The Decree of 29 December 2000 on detailed principles of financial management of the budgetary entities, budgetary enterprises and auxiliary facilities of the budgetary entities, detailed principles and due dates of annual accounts and budget contributions made by the budgetary enterprises and the auxiliary facilities of the budgetary entities (Journal of Laws No. 122, Item 1333).

A Government statement of 14 July 1994 on the ratification of the European Charter of Local Self-Government by the Republic of Poland, drawn up in Strasbourg on 15 October 1985, (Journal of Laws No. 124, Item 608). 